\title{
Old West Meets New West: A Story of Modern Cowboys and Native Americans in the Northwest
}

\section{By Laura Gow}

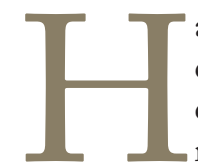
arney County, Oregon, ranks ninth among counties in the United States for beef cattle production with nearly half of the county taxes realized from the ranching community. ${ }^{1}$ Harney County is also the ninth largest county in the United States $(10,200$ square miles) and is larger than 8 states.

Located in southeast Oregon at the northern edge of the Great Basin, the climate of the area is characterized by

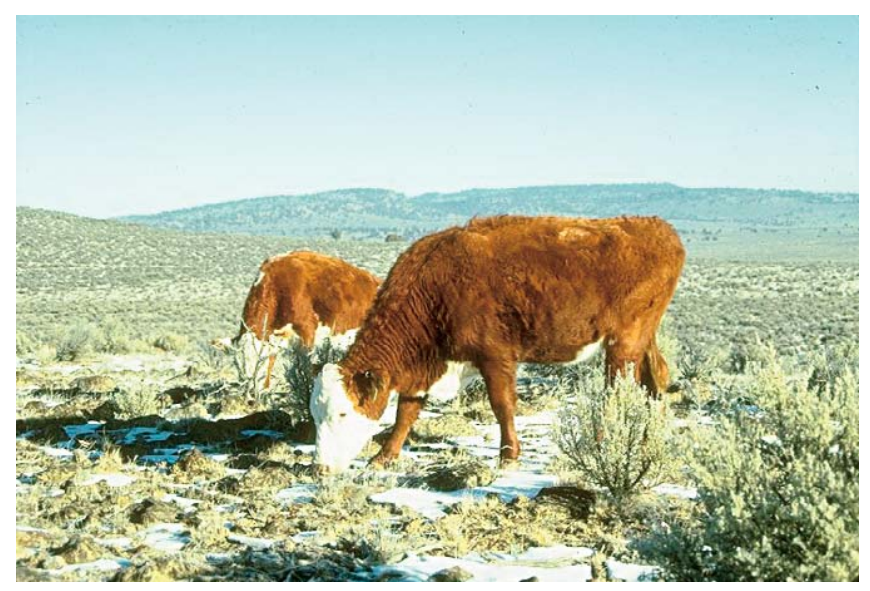

Photo 1. High-desert rangelands in Harney County, Oregon.

extremes in temperature with bitterly cold winters, hot summer days, and broad daily temperature fluctuations (often more than $50^{\circ}$ a day). The frost-free growing season is usually less than 60 consecutive days. Precipitation averages 8-14 inches in the lowlands and 14-40 inches in the uplands. ${ }^{2}$

Harney County is not unlike many rural counties in America today that are experiencing population out-migra- tion, high unemployment, resource conflicts, and a lack of industry. Oregon Employment Department (2004) statistics indicate the government is the largest employer in the county, with approximately one-third of all jobs, and agriculture accounting for approximately $25 \%$ of all jobs. ${ }^{3}$ In 2003 , the annual unemployment rate averaged $11.3 \%$ and roughly $7 \%$ of job seekers left the county in search of better employment opportunities. ${ }^{3}$ Also in Harney County, located just north of Burns, Oregon, is the Burns Paiute Tribe. Today there are almost 300 enrolled tribal members, but less than $37 \%$ reside permanently on the reservation. Due to the economic conditions and the remoteness of the county, identifying economic activities and employment-generating opportunities have been a constant priority for the tribe. ${ }^{4}$

\section{Cowboys and Native Americans}

The tribe had already established a successful casino and campground in the area, so given the resources of the area and the strong local cattle economy, a logical option for the tribe to consider was cattle production. While livestock production is not new to the Native American culture, cattle production can be considered a relative newcomer to the Native American economy. Several tribes have very well organized grazing permit programs for tribal lands that are available to both individual tribe members as well as nontribal ranchers. Throughout the West, Native Americans have been involved in raising sheep and goats, and many Northwest tribes, such as the Nez Perce, the Palouse, and the Cayuse, were known for horse breeding and trading from as early as the 1700s and actively managed large herds of horses grazing throughout the Northwest. However, very few tribes have been actively involved in the direct ownership of 


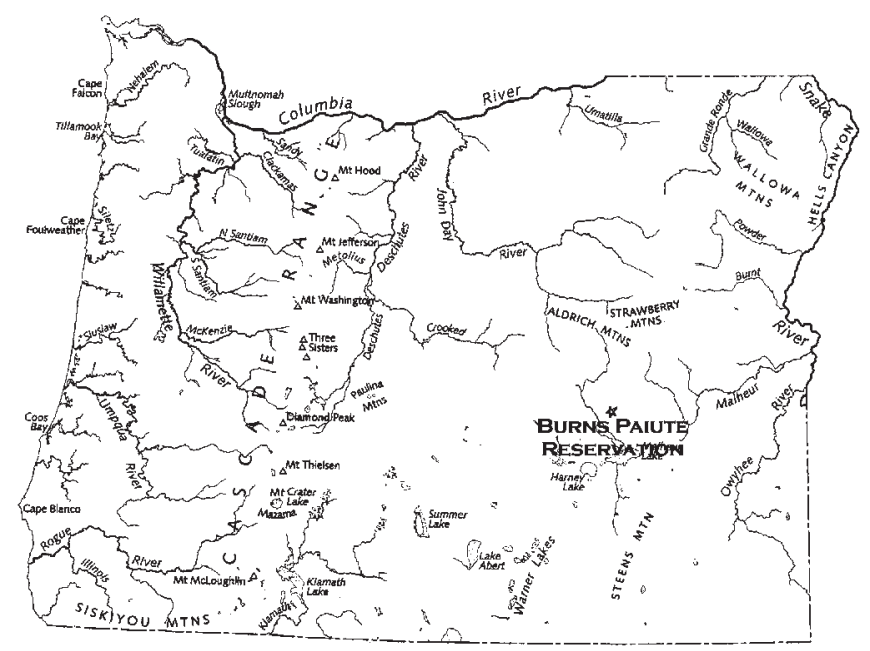

Map 1. Location of Burns Paiute Tribe. Map image from the Atlas of Oregon (2nd Ed.), copyright 2001 University of Oregon Press.

cattle, and the management of cattle can be considered a relatively new enterprise for tribes. Looking at their tribal neighbors to the north, they found some interesting results.

The Umatilla Confederated Tribes (UCT) located to the north of the Burns Paiute Tribe had seen tremendous economic growth and success from their casino, RV park, hotel, and golf course and began looking toward cattle as a way to expand and diversify their economic base. The UCT's approach to entering into the cattle industry was a unique and controversial one that brought much attention from the cattleman in Oregon. Umatilla's approach was to assert treaty-grazing rights on federal grazing lands, which was something no other tribe at the time had done.

The basis for UCT's approach had deep-seated historical roots, stemming back to an 1855 treaty that the U.S. government signed with each of the tribes of the UCT (Umatilla, Cayuse, and Walla Walla). The conditions of the treaty were such that the tribe ceded 6.4 million acres of their homeland to the U.S. government but retained the right to hunt, fish, gather berries and other vegetation, and graze livestock. Specifically, the treaty stated that "the privilege of hunting, gathering roots and berries and pasturing their stock on unclaimed lands in common with citizens, is also secured to (said Indians)." ${ }^{5}$

In the 21st century, the tribe decided to act on this right by using U.S. Forest Service land in the Blue Mountains of eastern Oregon for summer grazing. However, the Oregon Cattleman's Association (OCA) argued that this definition did not apply to federal grazing lands, as federal grazing permits excluded others from the right to use those lands just as a private purchase or private lease would exclude others from joint use of the land. Therefore, these lands were not considered "unclaimed lands."
Controversy ran amok throughout the cattle producers in the state based on the definition of "unclaimed lands." The OCA asserted that federal permit holders own the grass on federal lands and that it was a property right that could not be taken away and as such could not be considered unclaimed lands. The ranchers in the state did not want to exclude the UCT from using those lands, but they did not want to see the Native Americans receiving preferential treatment to grazing allotments. However, at the same time, the federal government did not dispute that the tribe retained their grazing rights through the 1855 treaty.

These disputes over returning grazing rights to the UCT had left a bad taste in many people's mouths throughout the state. The Burns Paiute Tribe decided they would investigate the feasibility of a tribe cattle operation based on their existing lands and did not want to follow the path that the Umatilla tribes had followed.

\section{The Old West}

The U.S. government's policy on the management and dissemination of Native American lands has varied throughout history. This has resulted in a variety of types of Native American landownership: tribal, individual Native American, as well as a mix of trust and fee lands. Trust lands are lands in which the title is held in trust and protected by the federal government. The tribe or individual Native American has use of the land, but ultimate control of the land remains with the federal government. The term "fee" is a legal term that refers to someone being in absolute and legal possession of property and does not refer to a payment for use. This pattern of landownership is commonly referred to as checkerboarding and can affect the ability of tribes or individual tribal members to use the land for farming, for ranching, as a home site, or for development.

Since the mid-1800s, the U.S. policy regarding the allocation of Native American land has been an evolving process. Initially, the prevailing policy was to segregate lands for the exclusive use and control of Native American tribes (ie, reservations). This policy has given way to the idea of allotting land to individual Native Americans. These parcels, or allotments, were held in trust by the government for no less than 25 years with the intent of eventually turning over complete ownership and control of the land to the individual Native American. After the 25 years had passed and the secretary of the interior was satisfied that an allottee was competent and capable of managing his or her affairs, the government would issue a fee patent (title). A fee patent typically coveys title of the land to the Native American from the U.S. government. Prior to that, a Native American could not sell, transfer, or enter into a contract for the sale or transfer of that land.

However, this policy of allotment came to an end in 1934 when Congress halted further allotments to individual Native Americans and extended indefinitely the existing periods of trust for allotment lands that had not been 
issued fee patents. The policy was then to return unallotted surplus Native American lands to tribal ownership or to be held in trust for the tribes. As a result of this changing government policy, there are a variety of ways in which we see Native American lands being owned today. Native American land may be owned by land held in trust for tribes as reservations, land allotted to individual Native Americans that is still held in trust by the federal government, land originally allotted to individual Native Americans who now hold title to the land, nontribal members who have acquired land from Native Americans who hold title to the land, and land owned by individual Native Americans or tribes outside of reservation boundaries and acquired from non-Native Americans.

The Burns Paiute had lived on the Malheur Reservation, which consisted of approximately 1.7 million acres in southeast Oregon. The reservation was reserved for all bands of Native Americans that were still "wandering" or living seminomadic lifestyles at the time. The Burns Paiute were part of one such tribe, the Northern Paiutes. The Northern Paiute Tribe was made up of small, peaceful bands that roamed throughout central and eastern Oregon prior to settlement in the late 1800s. In 1883, the government converted the reservation to public domain, which opened the land for white settlers to claim under the Homestead Act. At this time, the federal government allotted 160 -acre parcels to individual Native Americans who had lived on the Malheur Reservations. These allotments were located in what is today Harney County.

Only 115 allotments were given to the Burns Paiute tribe even though many more individuals were eligible to receive an allotment. Distrust and fear of the government led many tribal members to believe that this was some sort of a trick. Consequently, many Native American families camped near the towns of Burns and Drewsey and found seasonal work with ranches.

Today, the Burns Paiute Tribe has acquired several thousand additional acres outside the reservation to manage for conservation and ranching purposes. In the past decade, they have acquired a 6,450-acre cattle ranch on the Malheur River and a 1,760-acre ranch in Logan Valley. The tribe was able to acquire these ranch lands through funds provided by the Bonneville Power Administration (BPA) wildlife mitigation program. The BPA uses funds directed by Congress to compensate the public for wildlife habitat lost when dams were built on the Columbia River in the early 1900s.

The tribe proposed extensive wildlife mitigation, vegetation, and riparian projects on these properties and worked closely with an advisory group consisting of federal and state agencies, private organizations, and community members to develop a comprehensive management plan. The tribe's ongoing management objectives for these acres are to maintain sustainable levels of cattle production; repair riparian areas; control weeds; improve habitat for elk, deer, antelope, marmot, and sage grouse; and protect historical cultural sites left by the tribe's ancestors.

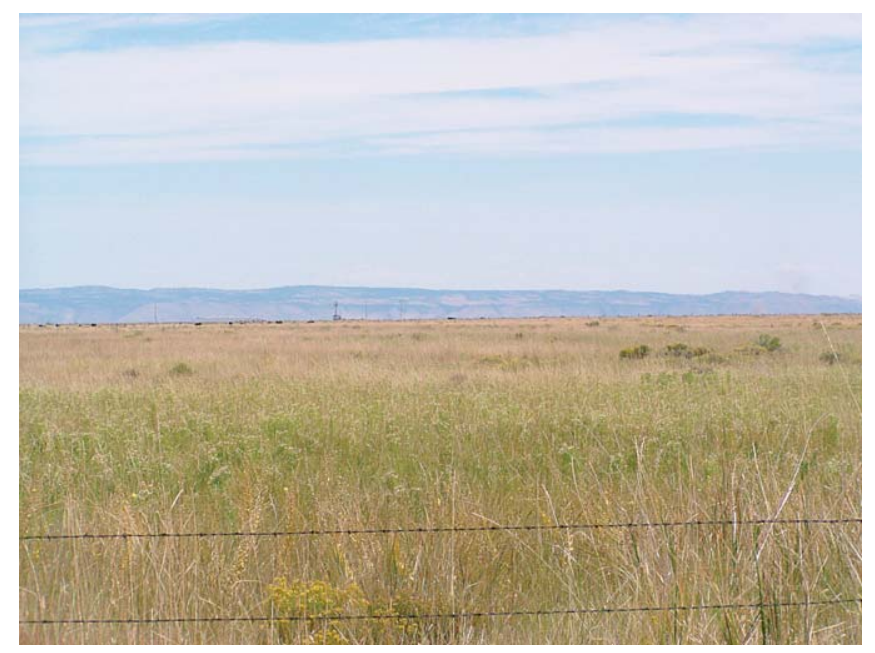

Photo 2. Pasture land in Harney County, Oregon. Source: Eastern Oregon Agricultural Research Center, Burns Station.

The Burns Paiute Tribe also has reservation land that covers 930 acres of trust land, 320 acres of fee-patent land, and another 11,000 plus acres of allotted lands held in trust for individual tribal members.

\section{Got Beef?}

So the question remained whether the tribe could feasibly operate a tribally owned and operated cattle operation. What opportunities would there be for a tribal cattle operation? Could they create a niche for their product? Would it be possible to integrate the various lands held by the tribe and individual tribal members to provide for adequate haying and grazing resources for a herd of cattle?

In Harney County, the government owns $76 \%$ of the land, which makes for a relatively limited supply of private land available for any use. ${ }^{2}$ To be successful in raising cattle in the high desert of Oregon, it essential that one have access to adequate rangelands for grazing. Therefore, in Harney County, grazing typically relies on obtaining a government allotment from the Bureau of Land Management, the U.S. Forest Service, or Oregon State Land (ie, grazing permit) or purchasing or leasing some of the limited supply of private land. As in most western states, grazing allotments are in limited supply and often very difficult to come by, and access to private land can be limited. Therefore, entering into ranching or expanding grazing activities for the general population of Harney County can often be very difficult.

The Burns Paiute Tribe had several forage resources available to utilize in a cow-calf operation. These forage resources include native rangelands as well as irrigated and nonirrigated hay ground. With a well-devised management plan that would include feeding of grass, feeding of alfalfa hay, and grazing of pasture and rangelands, the tribe could successfully operate a 250-350-head cow-calf operation. For Harney County, a 250-350-head operation would be considered relatively small and not a large generator of economic activity by 
itself. It is relatively easy to run $250-350$ with a few key employees and a few seasonal employees. However, it does not create a lot of employment opportunities for the tribe and the county. So the larger question for the tribe still remains. What could they do with their available resources that would provide economic activities and generate employment?

Many successful cow-calf operations have turned to the idea of vertical integration for long-term success in the cattle industry. The term "vertical integration" refers to producers owning or controlling the activities that are ahead or behind them in the total production process. In agriculture, this includes all the activities involved in bringing a product from the farmgate to the consumer plate. In the case of the tribe, they could consider stocking or backgrounding activities, retaining ownership of animals, finishing animals, and smallscale slaughter and processing. In addition, other employment-generating activities that could be considered would be expanding the operation, diversifying the operation into sheep or goats, establishing a purebred component to the operation, and an artificial insemination breeding program.

\section{Into the New West}

Coupled with these activities, the tribe could also consider niche marketing their beef products under a tribal brand. Niche marketing targets a subset of consumers who are not being readily served by the traditional products in the market. Niche marketing focuses on specialty products that are designed to be marketed to a very well defined set of consumers. Low profitability in the beef industry along with changes in consumer tastes and preferences have led many small producers to consider niche markets for their products. Niche marketing generally results in higher production costs but also usually sees higher returns over conventional marketing alternatives.

Recently, there have been several successful niche-marketing programs with natural beef products. The U.S. Department of Agriculture defines a natural product as one that contains no artificial or added color and is only minimally processed (ground, frozen, or smoked). In addition, the product must explain the use of the term "natural," such as "no added colorings" or "no artificial ingredients." Many natural beef products promote their products on the basis of the lack of hormone and subtherapeutic (fed) antibiotic use and animals being grass fed. The nature of this cattle enterprise could provide just such an opportunity to market their product as an all-natural Native American product.

More and more tribes are beginning to look at their identity as a source of marketing power. They are beginning to realize, as more and more niche markets develop for natural products, that there is the possibility of using Native American branding and labeling of products as a means to differentiate their products in the market. Labeling of Native American products can focus on many of the positive stereotypes associated with the ways of the Native American and western culture. It can focus on Native
Americans' strong beliefs and respect of nature as a cornerstone to the marketing of their products. Many consumers consider the Native American culture to exemplify the natural lifestyle they desire. This image could go a long way in the marketing of a Native American natural beef product. This could provide an excellent opportunity to market not only a natural beef product that was born, raised, and slaughtered in the United States but also one that was done by the original environmental stewards who know what conservation is all about.

Today, the economy of the Burns Paiute Tribe still remains closely tied to the economic activities of Harney County, which are centered primarily around agriculture production, the lumber industry and government services. Some tribal members are employed in these industries, but unemployment on and off the reservation still remains high. ${ }^{6}$ The tribe still continues to investigate the feasibility of alternatives for employment-generating activities and economic development projects and works closely with local and county governments. In recent years, they have worked on a distribution center, bottled water processing, and casino-related activities and have upgraded facilities on the reservation. In 2004, the tribe also applied to form a corporation to better compete for federal contracts. Currently, they are focusing on taking over the management of a state archive center and expanding the services provided in this data warehouse. Value-added and niche marketing activities will be something they continue to investigate in the future.

Author is Assistant Professor, AREC Department, OSU Agricultural Program at EOU, Oregon State University, La Grande, Oregon97850,lgow@eou.edu.

\section{References}

1. Yohannan, J. 2004. 2002 Census of Agriculture Results. Oregon Labor Market Information System, Oregon Employment Department. Available at: http://www.olmis.org/ olmisj/ArticleReader?p_search=harney+county\&searchtech=1 \&itemid=00003806. Accessed 6 January 2006.

2. Harney County Chamber of Commerce. Gateway to the Steens. Available at: http://www.harneycounty.com/ alvordranch/cattleranching.htm. Accessed 6 January 2006.

3. Oregon Employment Department. 2004. Labor Force, Employment and Unemployment Report. Available at: http://www.olmis.org/olmisj/PubReader?itemid=00003881. Accessed 6 January 2006.

4. Yohannan, J. 2002. Overview of Economic Conditions in Harney County. Oregon Labor Market Information System, Oregon Employment Department. Available at: http:// www.olmis.org/olmisj/ArticleReader?p_search=harney+county\& searchtech=1\&itemid=00002618. Accessed 6 January 2006.

5. United States Office of Indian Affairs. Treaty with the Cayuse, Walla Walla, and Umatilla, 1855. Available at: http:// www.umatilla.nsn.us/treaty.html. Accessed 6 January 2006. 